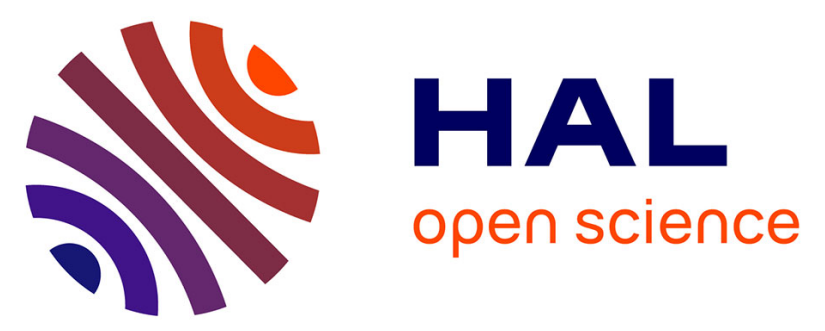

\title{
The Importance of Emerging Markets for Petroleum Technology Companies in Norway: Management and Entry Operation Strategies
}

Jan Frick, Murshid Mikael Ali

\section{- To cite this version:}

Jan Frick, Murshid Mikael Ali. The Importance of Emerging Markets for Petroleum Technology Companies in Norway: Management and Entry Operation Strategies. IFIP International Conference on Advances in Production Management Systems (APMS), Sep 2014, Ajaccio, France. pp.481-488, 10.1007/978-3-662-44733-8_60. hal-01387291

\section{HAL Id: hal-01387291 \\ https://hal.inria.fr/hal-01387291}

Submitted on 25 Oct 2016

HAL is a multi-disciplinary open access archive for the deposit and dissemination of scientific research documents, whether they are published or not. The documents may come from teaching and research institutions in France or abroad, or from public or private research centers.
L'archive ouverte pluridisciplinaire HAL, est destinée au dépôt et à la diffusion de documents scientifiques de niveau recherche, publiés ou non, émanant des établissements d'enseignement et de recherche français ou étrangers, des laboratoires publics ou privés.

\section{(c)(1)}

Distributed under a Creative Commons Attribution| 4.0 International License 


\title{
The importance of emerging markets for petroleum technology companies in Norway: Management and entry operation strategies.
}

\author{
Jan Frick, Murshid M. Ali \\ University of Stavanger, Stavanger, Norway \\ jan.frick@uis.no, murshid.ali@uis.no
}

\begin{abstract}
The petroleum industry today are characterised by local companies emerging to other markets. This paper evaluates from cases the importance of these markets, and how many actually export to them. The offshore technology petroleum industry is one of Norway's largest industry sectors. The main competitive advantage of this sector is its knowledge base. An important part of the industry supplies platforms and other highly specialised equipment to the petroleum industry. Constraints to achieving success in these markets are many; official data may be unreliable, corruption might flourish, there will be large cultural differences and the political and legal risks might be high. Prejudice against different societies can also be an obstacle in creating and developing organizations that promote trade.
\end{abstract}

Keywords: petroleum industry; competitive advantage; globalization

\section{Introduction}

Multinational companies from developed countries are enhancing their presence in emerging markets because they see the impact on growth and related bottom-line effects of their decisions and actions. They have increased their competitiveness by engaging in emerging markets performance enhancing activities. Growth in any market opens up the necessity for exchange of knowledge and technology. Especially in the postfinancial crisis era, companies from developed countries can spot opportunities in emerging markets.

According to the United Nations there are over sixty thousand firms operating internationally controlling at least half a million foreign affiliates. Together they produce goods worth more than eleven trillion USD. The trade between these companies have increased faster than the world trade overall (World Economic Forum, 2008). Private companies, through efficient organizations and capitalistic principles implement faster routines to enter new markets than others. These companies are now the global economy and drive the growth of different countries (UNCTAD, 2004). At the same time the largest economic growth of today is based in emerging countries. There is 
a shift in the world's economic power, from the West to the East (Enderwick, 2009). Usually globalization has been mentioned to describe free trade in goods and services, but the fast expansion of today's technological development has created a global arena of transfers of jobs and skills across borders, outsourcing and off shoring in order to cut costs. Part of the fastpaced globalization has occurred because companies find it hard to achieve growth in the already developed world. So they tend to turn against emerging markets, realizing that they yield better sales growth than can be found in the developed world (Pacek et al. 2007).

Business operations in emerging markets are a concept that is gaining popularity among many multinationals today. For many organizations it is not only a way of expanding their business, but also a part of the globalization that takes place around us today. Emerging markets accounted for about half of the world's GDP in 2006 and these markets continue to demonstrate a tremendous growth that outpaces those of the already developed markets (Pacek et al. 2007). As a result, many companies see the ability to sell effectively to these markets as integral to their long-term survival in an ever-increasing competitive environment. Business conducted in emerging markets enables companies to achieve lower production costs, gain access to new customers, obtain access to information or resources and spread business risk. This will also help companies react more quickly to changes in the market, and respond more promptly to customer requests.

\section{Characteristics of emerging markets}

- Countries generally considered to be emerging markets, possess some, but not necessarily all of the following

- Per capita income of less than US \$10,725 (the current World Bank definition of low and middle income economies)

- Recent or relatively recent economic liberalisation

- Debt ratings below investment grade by major international ratings agencies

- Recent liberalisation of the political system and a move towards greater public participation in the political process

Studies of the different emerging markets have become more and more important, and several leading organizations have conducted studies on the subject and gives out yearly rankings. The most well-recognized and popular ranking of competitiveness of countries is the Global Competitiveness Rankings and World Competitiveness rankings.

The World Economic Forum conducts the Global Competitiveness Rankings study. Competitiveness is defined as the collection of factors, policies and 
institutions that determine the level of productivity of a country and thus determine the level of prosperity that can be attained by an economy.

The annual World Competitive Index is given by IMD. Competitiveness of nations could be described as an integrative process of all policies in a country in order to have a blueprint to increase prosperity (IMD, 2006). The World Competitiveness Index has four components, namely, economic performance, government efficiency, business efficiency and infrastructure. Knowledge has emerged and is accepted as the most critical resource (Bartlett and Ghosal, 1993; Moffet et al, 2010; Pillania, 2006). The main producers of wealth are information and knowledge generators (Moffet, 2010). Knowledge has an important role in advancing economic and social wellbeing and poor countries differ from rich ones not only because they have less capital, but also because they have less knowledge (World Economic Forum, 2008). Management scholars today consider knowledge and the ability to create and utilize knowledge to be the most important source of a firm's sustainable competitive advantage (Pillania, 2005).

\section{How important is emerging markets in the oil industry today?}

To understand the importance of emerging markets for Norwegian companies within the petroleum industry, we should assess the upstream sites of one of the largest oil producers in the world. ExxonMobil is the largest oil company in the world, having a turnover of 1515 billion USD in 2013, and over 70000 employees. An overview of the upstream activities shows that most of activities in production stem from emerging markets, and most of the major sites and new additions are also in connection to emerging markets. This indicates future activity that is expected to rise in these areas. These activities are also centred and mainly focused on emerging markets. For petroleum technology companies that offer new and more efficient technology, this is valuable information in order to understand where the future market for their products and services will be. The end-client for all of the case companies in this paper is eventually the petroleum operators such as BP, ExxonMobil, ConocoPhillips, Statoil and so forth.

\section{Strategies to enter emerging markets}

When companies go global they will have to establish a global distribution system and an integrated manufacturing capability, and these factors gives the company a competitive advantage. However, going global poses also a lot of challenges, such as variety of commercial invoices, different bills of lading, and inspection certificates and in addition the company needs to comply with new domestic and international regulations. This will be 
discussed in the following chapters. According to Hisrich and al., there are different modes of entering or engaging in international business, these modes can be divided into three categories: Exporting, non equity arrangements as in turn-key contracts and licensing, and direct foreign investment as in joint ventures and wholly owned subsidiaries (see table under).

\begin{tabular}{|c|c|c|}
\hline Entry Mode & Advantage & Disadvantage \\
\hline Exporting & $\begin{array}{l}\text { - Ability to realize location } \\
\text { and experience curve } \\
\text { economies }\end{array}$ & $\begin{array}{l}\text { - High transport costs } \\
\text { - Trade barriers } \\
\text { - Problems with local marketing } \\
\text { agents }\end{array}$ \\
\hline $\begin{array}{l}\text { Turn-key } \\
\text { contracts }\end{array}$ & $\begin{array}{l}\text { - Ability to enter returns } \\
\text { from process technology } \\
\text { skills in countries where } \\
\text { FDI is restricted }\end{array}$ & $\begin{array}{l}\text { - Creation of efficient competitors } \\
\text { - Lack of long-term market presence }\end{array}$ \\
\hline Licensing & $\begin{array}{l}\text { - Low development costs } \\
\text { and risks }\end{array}$ & $\begin{array}{l}\text { - Lack of control over technology } \\
\text { - Inability to engage in global } \\
\text { strategic coordination }\end{array}$ \\
\hline Franchising & $\begin{array}{l}\text { - Low development costs } \\
\text { and risks }\end{array}$ & $\begin{array}{l}\text { - Lack of control over quality } \\
\text { - Inability to engage in global } \\
\text { strategic coordination }\end{array}$ \\
\hline Joint Ventures & $\begin{array}{l}\text { - Access to local partner's } \\
\text { knowledge-based } \\
\text { - Shared development } \\
\text { costs and risks } \\
\text { - Politically acceptable }\end{array}$ & $\begin{array}{l}\text { - Lack of control over technology } \\
\text { - Inability to engage in global } \\
\text { strategic coordination } \\
\text { - Inability to realize location and } \\
\text { experience curve economies }\end{array}$ \\
\hline $\begin{array}{l}\text { Wholly owned } \\
\text { subsidiaries }\end{array}$ & $\begin{array}{l}\text { - Protection of technology } \\
\text { - Ability to engage in } \\
\text { global strategic } \\
\text { coordination }\end{array}$ & - High costs and risks \\
\hline
\end{tabular}

(From Hisrich et al. 2011, page 531)

The most common way of starting an international venture is through exporting. Exporting is when a company or an organization sells and ships products or services manufactured in one country to another country. Towards the emerging market, Norwegian companies needs to have an emerging market agent that purchases the products or the services, and then sells them to the end costumer. Non-equity arrangements consist of licensing and turnkey projects. Joint ventures and wholly owned subsidiaries makes the Norwegian companies obliged to invest in Emerging markets, and be a part of the economical sphere there, thus an direct foreign investment. 


\section{Methodology}

This paper is based on data collected through interviews of 40 different companies in the oil industry in near proximity to Stavanger. In addition all of the companies are characterised as Petroleum technology, this was also a prerequisite in order to be able to participate in the analysis. The primary source for this study was a semi-structured interview with 10 questions, in addition to an open and informal interview style in order to understand and get to know the organization and management on a deeper level. A typical interview lasted for about 60 minutes, with additional open-ended questions in order to understand the importance of sales and marketing in emerging markets for these companies.

\section{Case companies}

\begin{tabular}{|l|l|l|l|}
\hline 1 & Petroleum Tech Company AS & 21 & Module Solutions and Systems AS \\
\hline 2 & Roxel elektro automasjon & 22 & MT Technology \\
\hline 3 & Roxel Aanestad & 23 & Norwegian Hose Supply \\
\hline 4 & Roxel AS & 24 & Norwegian Oilfield supply \\
\hline 5 & Roxel Building Technologies & 25 & NOT AS \\
\hline 6 & Roxel Energy & 26 & Align AS \\
\hline 7 & Roxel Hvac & 27 & Completion Tech Resources AS \\
\hline 8 & Roxel Klima & 28 & Vision Io AS \\
\hline 9 & Roxel Products & 29 & IK Stavanger AS \\
\hline 10 & Roxel Solutions & 30 & Oneco Technology AS \\
\hline 11 & Stream AS & 31 & Oneco Solutions AS \\
\hline 12 & Wiretech AS & 32 & Fjell Industrier AS \\
\hline 13 & Xnor AS & 33 & Flowtec AS \\
\hline 14 & Albatross Elektro AS & 34 & Hitec Products AS \\
\hline 15 & Albatross Services AS & 35 & Light Weight Drilling AS \\
\hline 16 & Aseon AS & 36 & Metallteknikk AS \\
\hline 17 & IKM Testing AS & 37 & Norwegian Coating Technology AS \\
\hline 18 & Bri Cleanup AS & 38 & Eureka Pumps AS \\
\hline 19 & Bri Wellservice AS & 39 & Oil Treatment Technologies AS \\
\hline 20 & Cyviz AS & 40 & Bolt Norge AS \\
\hline
\end{tabular}

\subsection{Case study objectives}

1) To understand if Norwegian petroleum technology companies are expanding to emerging markets.

2) Which emerging markets they operate in.

3) What kind of entry-strategy they use when entering into emerging markets.

4) Who in the organization are responsible for the export and establishment effort in emerging markets? 


\section{Study results}

All of the interviews were done with the top management of all of the companies. Top management is characterized by being one of the owners, CEO, CTO or others with key supervisory responsibilities. This has given this paper a unique insight into the management patterns of highly entrepreneurial companies during export to foreign countries, effectively mapping the most relevant countries.

- Top management gave $100 \%$ of the interviews.

- $75 \%$ of the companies operate within upstream, $25 \%$ within downstream.

- $100 \%$ of the companies export to foreign countries.

- $82 \%$ of the companies export to emerging markets.

- The most important emerging market was listed to be Middle East, with Brazil following closely afterwards.

- Only $25,5 \%$ has an office in an emerging market. Of these average age in the markets were 3,5 years.

- When exporting to emerging markets, these where the statistics on the different entry-modes:

\begin{tabular}{|l|l|}
\hline Entry Mode & Total companies \\
\hline Exporting & $100 \%$ \\
\hline Turn-key contracts & $12,5 \%$ \\
\hline Licensing & $57,6 \%$ \\
\hline Agent & $55 \%$ \\
\hline Joint Ventures & $63,5 \%$ \\
\hline Wholly owned subsidiaries & $25,5 \%$ \\
\hline
\end{tabular}

- $72,5 \%$ cited that emerging markets were very important for their business, $17,5 \%$ said it was important, while approx. $10 \%$ claimed it to be less important.

- In $95 \%$ of all case companies, the top management were in charge of the operations towards emerging markets.

It is quite evident that emerging markets are important for most of the companies surveyed. A surprising fact is also that all companies have, at least 
once, exported products or services to foreign countries. One of the groups interviewed, Roxel Group, consists of several daughter companies who all fall under the SME and technology definition. In addition BR Industries were surveyed. This industrial group is one of the largest in Rogaland. Several of the companies surveyed belong to BR Industries. The case studies and interviews suggests that the oil technology companies have been clever in following the footsteps of the larger oil operators. We can refer back to our assessment and analysis of ExxonMobil and their focus of expanding operations. Interestingly but not surprisingly the Middle East were the most common emerging market to expand into.

Norwegian companies are eager to investigate possibilities and expand into new international markets as their own market space is becoming more and more competitive. Emerging markets has a good impression of Norwegian companies and is interested in cooperating with them in order to do business and create new opportunities. However, another interesting fact from the research shows that many of the companies just recently have established a link or a connection to emerging markets. The average age of being established were only 3,5 years for those companies who had an office in these markets. This suggests that our case companies just recently have acknowledged the importance of the emerging markets. Our discussions with those companies that have established themselves in emerging markets thus suggest that the Norwegian companies needs to invest in emerging markets for the long run and cannot expect to "take over" the market space in matter of months. The competition in emerging markets is fierce, but the benefits are great for the companies that think tactically and plan accordingly. Large cultural, religious and language differences are also often a barrier, however with time they are overcome.

\section{Conclusions}

Our research shows that the Norwegian companies surveyed are expanding and exporting to emerging markets, thus shown that they have acknowledged the importance of these markets to their companies. The emerging markets that they choose to expand to, and do business in - are mainly markets where large and known petroleum operators already do business. This is quite common in the petroleum industry, as our research also supports. Smaller companies, such as technology intensive SME, follows the larger corporations out into the rest of the world. For many of the companies that were investigated, much of their revenues, to an increasing extent came from emerging markets. The most popular mode of entry for most companies is exporting directly to the different markets. The importance of emerging markets are also evident for these companies, due to that almost all companies have assigned the task of expansion in these markets to someone in the top management of each company. The emerging markets are quite 
important for Norwegian SME technology companies within the petroleum industry, and that they are quite good in expanding to these market and that they have highly prioritized their operation strategies towards emerging markets.

\section{Further research}

The authors of this paper recommends further research on the topic, especially in order to understand if there are differences in strategies when operating in different emerging markets.

\section{References}

Enderwick, P. "Responding to global crisis: the contribution of emerging markets to strategic adaptation." International Journal of Emerging Markets, Vol. 4, pp. 358-374. (2009)

Bartlett, C.A. and Ghosal, S. "Beyond the M-form: toward a managerial theory of the firm", Strategic Management Journal, Vol. 14, pp. 23-44. (1993)

Pillania, R. K. “Competitiveness and emerging markets.” Business Strategy Series, Vol. 10, pp. 90-95. (2009)

Pillania, R. K. "Leveraging knowledge for sustainable competitiveness in SMEs", International Journal Globalization and Small Business, Vol. 1, pp. 27-39 (2006)

Moffet, M., Ronkainen I., and Czinkota, M. "International Business", 8th edition, John Wiley \& Sons (2010)

Robert D. Hisrich, Michael P. Peters and Dean A. Shepherd;

Entrepreneurship, 7th edition, McGraw-Hill International Edition (2008)

Robert D. Hisrich; International Entrepreneurship: Starting, Developing, and Managing a Global Venture, 2th edition, Sage Publications (2012)

Pacek, N and Thorniley D. "Emerging Markets: Lessons for Business

Success and the Outlook for Different Markets", John Wiley \& Sons (2007)

IMD, World Competitiveness Yearbook 2006, IMD, Geneva:

http://www.imd.org/wcc (2006)

World Economic Forum, Global Competitiveness Report 2008, Oxford

University Press, New York, NY (2008)

UNCTAD, World Investment report, New York and Geneva: United Nations Conference on Trade and Development (2004) 